\title{
The impact of introduced Ponto-Caspian mysids (Paramysis lacustris) on the trophic position of perch (Perca fluviatilis) in European mesotrophic lakes
}

\author{
Vytautas Rakauskas* \\ Laboratory of Fish Ecology, Nature Research Centre, Akademijos St. 2, 08412 Vilnius-21, Lithuania
}

Received: 13 June 2019 / Accepted: 25 August 2019

\begin{abstract}
Paramysis lacustris was introduced into Lithuanian lakes in the middle of the 20th century. It was assumed that $P$. lacustris will enhance efficiency of primary production utilization and channelling of primary production towards higher trophic levels, i.e. commercially important fish species. However, at the time of $P$. lacustris introduction, there were no reliable data about its trophic position in lakes. Thus, $P$. lacustris was considered to have no or little impact on native ecosystems. Until now, there is a gap in the knowledge of the trophic role and potential impacts of $P$. lacustris on local food webs in lakes. Here we investigated the impact of $P$. lacustris on the food chain length of its potential predator Perca fluviatilis in temperate lakes. In this study, gut contents and stable isotope analyses were performed to assess the diet and trophic position of $P$. lacustris and $P$. fluviatilis in lakes with and without invasive mysids. The results obtained revealed that $P$. lacustris consumes a significant amount of animal prey and occupies the third trophic level in lake littoral zones. Furthermore, our results showed that $P$. lacustris might enhance the food chain length for at least some zooplanktivorous fishes. Overall, the assumption that $P$. lacustris invasion has no whole-ecosystem consequences, as it was thought before its introduction, is not correct.
\end{abstract}

Keywords: Aquatic invasion / food webs / fish diet / stable isotopes

Résumé - L'impact du mysidacé Ponto-Caspien introduit (Paramysis lacustris) sur la position trophique de la perche (Perca fluviatilis) dans des lacs mésotrophes européens. Paramysis lacustris a été introduite dans les lacs lituaniens au milieu du $\mathrm{xx}^{\mathrm{e}}$ siècle. On a supposé que $P$. lacustris améliorera l'efficacité de l'utilisation de la production primaire et le transfert de la production primaire vers les niveaux trophiques supérieurs, c'est-à-dire les espèces de poissons commercialement importantes. Cependant, au moment de l'introduction de P. lacustris, il n'existait pas de données fiables sur sa position trophique dans les lacs. Ainsi, P. lacustris a été supposé comme n'ayant pas ou peu d'impact sur les écosystèmes indigènes. Jusqu'à présent, il y a une lacune dans les connaissances sur le rôle trophique et les impacts potentiels de $P$. lacustris sur les réseaux trophiques locaux dans les lacs. Nous avons étudié ici l'impact de P. lacustris sur la longueur de la chaîne alimentaire de son prédateur potentiel Perca fluviatilis dans les lacs tempérés. Dans cette étude, on a effectué des analyses du contenu gastrique et des analyses des isotopes stables pour évaluer le régime alimentaire et la position trophique de $P$. lacustris et $P$. fluviatilis dans les lacs avec et sans mysidacé envahissant. Les résultats obtenus ont révélé que $P$. lacustris consomme une quantité importante de proies animales et occupe le troisième niveau trophique dans les zones littorales des lacs. De plus, nos résultats ont montré que $P$. lacustris pourrait augmenter la longueur de la chaîne alimentaire pour au moins certains poissons zooplanctonivores. Dans l'ensemble, l'hypothèse selon laquelle l'invasion de P. lacustris n'a pas de conséquences sur l'ensemble de l'écosystème, comme on le croyait avant son introduction, n'est pas correcte.

Mots-clés : Invasion aquatique / réseaux trophiques / alimentation des poissons / isotopes stables

\footnotetext{
*Corresponding author: vytucio@gmail.com
} 


\section{Introduction}

The problem of non-indigenous species invasion has persisted since the second half of the 20th century. Invasive species can cause food-web shifts that can have severe consequences for native species and ecosystems (David et al., 2017; Jackson et al., 2017). In aquatic ecosystems, Crustacea including Mysida, are the frequently observed groups of invasive species (Audzijonyte et al., 2017; Arbačiauskas et al., 2018; Borza et al., 2019). Mysids are known to play a significant role in the diet of freshwater fish (Bubinas, 1979; Kublickas and Bubinas, 1985; Lasenby et al., 1986). Therefore, several mysid species were intentionally released into water bodies throughout Eastern (Borodich and Havlena, 1973; Arbačiauskas et al., 2018) and Northern Europe (Lasenby et al., 1986; Ketelaars et al., 1999) and North America (Lasenby et al., 1986; Chess and Stanford, 1998) in order to increase fishery yields. The introduced mysids rapidly spread from original sites of introduction and are claimed to have caused perturbations in native food webs of the invaded habitats (Koksvik et al., 1991; Langeland et al., 1991; Spencer et al., 1991). The mechanisms through which these invaders affect native communities are still poorly understood and quantitative data are scarce.

Similarly, Paramysis lacustris (Czerniavsky, 1882) was deliberately introduced into inland waters of Lithuania (Arbačiauskas et al., 2018). Although P. lacustris failed to survive in most of the lakes into which it was introduced, it managed to establish sustainable populations in large lakes and water reservoirs. It was suggested that the best predictor of successful $P$. lacustris establishment in lakes was a larger surface area, faster water circulation and increased amount of total phosphorus (Arbačiauskas et al., 2018). However, in the lakes in which they survived, $P$. lacustris produced very abundant populations (Arbačiauskas et al., 2012).

When considering $P$. lacustris introductions, a major assumption of acclimatization was that there should be a free niche space. That was the case for introduction of $P$. lacustris to Lithuanian lakes, which were considered relatively poor in higher crustaceans due to geographical isolation (Gasiuūnas, 1963). Only one pelagic mysids species (Mysis relicta Lovén, 1862) was known from Lithuanian lakes before the introduction of $P$. lacustris. Thus, it was hypothesized that detritivorous and herbivorous littoral $P$. lacustris would obtain sufficient nutrition to develop high biomass and thus would supplement local invertebrate communities with highvalue fish food items. The expectation that the introduced $P$. lacustris will acclimatize and will subsequently enhance fish production was underpinned by the following three assumptions. Firstly, the introduced mysids species will provide high quality (high calorie) and easily accessible food for fish. As a result, fish nutrition and subsequent growth will improve, and the standing stock will increase (Gasiūnas, 1963). Secondly, mysids will be an alternative food (substituting fish fry) for predatory fish species during their ontogenetic transition to piscivory and will increase the efficiency of energy transfer by shortening the food chain length (Vaitonis et al., 1990). The third assumption was that the introduced mysids species would ensure constant food supply for benthivorous fish after hatching blooms of aquatic insects (Gasiūnas, 1963).
The introduction of novel species is always followed by consequences that are not necessarily such as expected. Previous studies showed that some introduced mysids species had a massive effect on plankton communities. Predation of mysids (Rieman and Falter, 1981; Koksvik et al., 1991; Langeland et al., 1991; Ketelaars et al., 1999; Spencer et al., 1999; Borcherding et al., 2006) caused a significant decline in the abundance, species richness and diversity of cladocerans, which led to a notable change in the fish diet content (Lasenby et al., 1986; Spencer et al., 1991). These consequences show that the real impact of mysids introduction on native communities cannot be predicted without the knowledge of the trophic position of the introduced mysids. However, despite the rapid spread of $P$. lacustris in Europe, there is little knowledge about potential consequences of their invasion for the native ecosystems in temperate lakes. Therefore, the trophic role of $P$. lacustris, and its potential to lengthen the trophic chain in lakes are of great scientific and applied interest.

The present study was undertaken chiefly with a view to determine potential impacts of invasive P. lacustris on local food chains in temperate lakes. Here we investigated the impact of the introduced mysid species on the trophic position of zooplanktivorous perch juveniles in mesotrophic lakes. Studies of these covered the following aims: (1) to explore the trophic niche of invasive mysids by applying stable isotope (carbon ${ }^{13} \mathrm{C} /{ }^{12} \mathrm{C}$ and nitrogen ${ }^{15} \mathrm{~N} /{ }^{14} \mathrm{~N}$ ) analysis (2) to evaluate the diet and the trophic position of Perca fluviatilis Linnaeus, 1758 juveniles in lakes with and without invasive mysids.

\section{Materials and methods}

\subsection{Studied lakes and sampling}

The impact of the introduced $P$. lacustris on the trophic position of $P$. fluviatilis was studied in 12 mesotrophic lakes in autumn 2010-2012. Morphometric characteristics and trophic status of lakes are presented in Table 1. All studied lakes are similar in their littoral fish communities. P. fluviatilis together with roach, Rutilus rutilus (Linnaeus, 1758) is the most dominant fish species in the littoral zone of the studied lakes. In addition to these dominant fish species, the littoral zone of the studied lakes is inhabited by other fish species, i.e. Gymnocephalus cernua (Linnaeus, 1758), Abramis brama (Linnaeus, 1758), Tinca tinca (Linnaeus, 1758), Blicca bjoerkna (Linnaeus, 1758) or Esox Lucius (Linnaeus, 1758) (see Virbickas, 2013). However, the presence of the introduced $P$. lacustris in these lakes is different.

For diet analysis, perch were sampled with a beach seine in the shallow littoral zone (down to $2.0 \mathrm{~m}$ depth). A beach seine with $8-$ or 7-m long wings (mesh size 10 and $5 \mathrm{~mm}$, respectively) was used; the opening of the seine bag was $1.2 \times 1.3 \mathrm{~m}$ (width $\times$ height), and the length of $3 \mathrm{~mm}$ meshsized cod-end was $3 \mathrm{~m}$. For gut content and stable isotope analysis, mysids were collected in the same littoral zone at 0.5-2.0 $\mathrm{m}$ depths using epibenthic sledge nets (opening $20 \times 60 \mathrm{~cm}$, mesh size $-500 \mu \mathrm{m}$ ). Molluscs (Radix sp.) were collected at the same time and the same place as mysids with a standard hydro biological hand net sampler (opening $25 \times 25 \mathrm{~cm}$, mesh size $-500 \mu \mathrm{m})$. Mesozooplankton samples (Daphnia spp.) were taken with $200 \mu \mathrm{m}$ zooplankton net by 
Table 1. Characteristics of the lakes and water reservoirs (WR) studied: surface area (S), mean depth (H), annual water circulation (AWC), annual average of chlorophyll a $(\mathrm{Chl})$, total nitrogen $\left(\mathrm{N}_{\mathrm{T}}\right)$, and total phosphorus $\left(\mathrm{P}_{\mathrm{T}}\right)$ (Anonymous, 2015). The presence of Paramysis lacustris is indicated by an asterisk.

\begin{tabular}{|c|c|c|c|c|c|c|c|c|}
\hline No. & Lake & S (ha) & $\mathrm{H}(\mathrm{m})$ & AWC (\%) & $\operatorname{Chl}(\mu \mathrm{g} / \mathrm{L})$ & $\mathrm{N}_{\mathrm{T}}(\mu \mathrm{g} / \mathrm{L})$ & $\mathrm{P}_{\mathrm{T}}(\mu \mathrm{g} / \mathrm{L})$ & P. lacustris \\
\hline 1 & Aisetas & 501 & 10.4 & 123 & 2.56 & 1280.7 & 22.6 & - \\
\hline 2 & Antalieptė WR & 1911 & 7.2 & 102 & 3.56 & 786.9 & 24.0 & $*$ \\
\hline 3 & Asveja & 982 & 14.9 & 46 & 3.76 & 999.9 & 14.1 & - \\
\hline 4 & Baluošas & 426 & 10.7 & 103 & 3.83 & 601.7 & 16.7 & - \\
\hline 5 & Daugai & 911 & 13.2 & 12 & 4.55 & 972.8 & 28.6 & $*$ \\
\hline 6 & Drūkšiai & 4480 & 7.6 & 29 & 8.35 & 1026.2 & 70.1 & $*$ \\
\hline 7 & Dusia & 2334 & 15.4 & 6 & 6.56 & 903.2 & 34.4 & $*$ \\
\hline 8 & Luodis & 1320 & 6.7 & 35 & 9.67 & 805.3 & 29.5 & - \\
\hline 9 & Lūšiai & 391 & 13.9 & 249 & 2.76 & 665.2 & 17.9 & $*$ \\
\hline 10 & Plateliai & 1182 & 11.4 & 12 & 2.65 & 593.5 & 21.8 & - \\
\hline 11 & Zarasas & 323 & 11.5 & 124 & 4.98 & 1208.1 & 19.1 & - \\
\hline 12 & Žeimenys & 436 & 6.9 & 698 & 12.18 & 749.5 & 39.7 & $*$ \\
\hline
\end{tabular}

filtering 30-500 L water from offshore stations (from 1.5, 2, and $3 \mathrm{~m}$ depths).

\subsection{Diet analysis}

The potential impact of $P$. lacustris on food chains of local fish was studied using $0+$ juveniles of perch as a model fish species. Previous investigations showed that introduced mysids, when abundant, are important food items in the diet of perch juveniles, which start consuming them from the age 0+ (Arbačiauskas et al., 2010; Rakauskas et al., 2010). Furthermore, it was revealed that in lakes with numerous populations of littoral mysids, the ontogenetic shift in perch diet (from zooplankton to macro invertebrates) occurs earlier, which is because of the availability of mysids as prey (Rakauskas et al., 2010).

Perch diet was studied in nine lakes, differing in the presence of $P$. lacustris. Up to 50 individuals of $P$. fluviatilis per lake were selected for diet analysis. In total, gut contents of 283 specimens were examined (fish with empty stomachs being excluded). After euthanization (by immersing into 1.5$2.0 \mathrm{ml} \mathrm{L}^{-1}$ solution of 2-phenoxyethanol for $5 \mathrm{~min}$ ), digestive tracts of selected fish were immediately removed and preserved in $10 \%$ formaldehyde solution until necropsy in the laboratory. Before food content analysis, specimens were measured to the nearest $1 \mathrm{~mm}$ (TL), weighed to the nearest $0.1 \mathrm{~g}$, their age being determined from operculum bones. Only first-year $(0+)$ juveniles $(<8 \mathrm{~mm} ; 6.6 \pm 0.7 \mathrm{~mm})$ were used for gut content analysis. Gut contents were dissected out, and food items were identified to the lowest possible level, grouped and weighed (wet-weight) to the nearest $0.1 \mathrm{mg}$. Digested and thus unidentifiable particles were classified as separate 'miscellaneous stomach content' and their share in the fish diet was presented under the category of "Other" prey. The data from individual fish specimens were averaged to obtain estimates of mean proportions of various preys in P. fluviatilis diet in each lake.

The diet of mysids was studied only in Daugai, Dusia and Lūšiai lakes. For diet analysis, mysids were collected during the daytime. Up to 30 individuals of $P$. lacustris per lake were selected for diet analysis. In total, gut contents of 64 specimens were examined (mysids with empty stomachs being excluded). Before analysis, the body length of mysids (BL, $\mathrm{mm}$ ) from the tip of the rostrum to the end of the telson was measured using an ocular micrometer $( \pm 0.1 \mathrm{~mm})$ under the stereomicroscope. Only large adults $(>10 \mathrm{~mm} ; 11.2 \pm 0.8 \mathrm{~mm}$ ) were used for gut content analysis. Gut contents were dissected out, and food items were identified to the lowest level possible, grouped, their volume proportion to the overall gut content being estimated (Hyslop, 1980). Digested and thus unidentifiable particles were classified as separate 'miscellaneous stomach content' and their share in mysids diet was presented under the category of "Detritus" prey. The data from individual mysid specimens were averaged to obtain estimates of mean proportions of various prey in P. lacustris diet in each lake.

\subsection{Stable isotope analysis (SIA)}

For stable isotope analysis, specimens of $P$. fluviatilis were taken from beach seine catches. Before analysis, selected perch specimens were measured. Only first-year juveniles $(0+)$ (TL $<8 \mathrm{~mm} ; 6.6 \pm 0.7 \mathrm{~mm})$ were used for SIA. The white muscle of fish was dissected from the dorsal part and placed into foil cups (three to six replicates per lake, 5 individuals per replicate). For SIA, live mysids were taken from epibenthic sledge catches and placed into filtered lake water. After transportation in coolers to the laboratory, the collected mysids were maintained alive for several hours to allow gut-content evacuation. Before analysis, the mysids were rinsed with distilled water and measured. Only large, whole-body adult mysids (BL $>10 \mathrm{~mm} ; 11.2 \pm 0.8 \mathrm{~mm}$ ) were used for SIA. The mysids collected in each lake were divided into three to eight analytical replicates, with 5 individuals per replicate. The collected snails were frozen before dissection. The shell height (SH) was measured to the nearest millimetre. Only large adults ( $\mathrm{SH}>14 \mathrm{~mm} ; 16.4 \pm 0.9 \mathrm{~mm}$ ) were used for SIA. Then the snails were separated from the shell material, their digestive gland was removed, and the remaining tissues were macerated. 
The collected snails were divided into three replicates per lake, five individuals per replicate. Upon return to the laboratory, the bulk of zooplankton was manually separated into copepods, cladocerans (Daphnia spp, in particular) and large Leptodora kindtii (Focke, 1844) using carbonated water to narcotise the organisms. Then Daphnia spp. was placed into filtered lake water for several hours to reduce the influence of gut contents on stable isotope results (Feuchtmayr and Grey, 2003). The separated Daphnia spp. samples were filtered through $25 \mathrm{~mm}$ Whatman GF/C filter paper. The whole concentrated bulk of Daphnia spp. was divided into three analytical replicates per lake.

All samples were oven-dried at $60{ }^{\circ} \mathrm{C}$ for $48 \mathrm{~h}$, ground to fine powder in an agate mortar. The samples were analyzed at Stable Isotope Facility, UC Davis, USA. Carbon and nitrogen stable isotope ratios were determined by continuous-flow isotope ratio mass spectrometry. Stable isotope ratios are given using the $\delta$ notation expressed in units per mil as follows: $\delta(\%)=\left[\left(R_{\text {sample }} / R_{\text {standard }}\right)-1\right] \times 1000$, and $\mathrm{R}=$ the ${ }^{13} \mathrm{C} /{ }^{12} \mathrm{C}$ or ${ }^{15} \mathrm{~N} /{ }^{14} \mathrm{~N}$. The global references were atmospheric $\mathrm{N}_{2}$ for the ${ }^{15} \mathrm{~N} /{ }^{14} \mathrm{~N}$ ratio, and Vienna Pee Dee belemnite for the ${ }^{13} \mathrm{C} /{ }^{12} \mathrm{C}$ ratio. Typical precision for a single analysis was $\pm 0.1 \%$ for $\delta^{13} \mathrm{C}$ and $\pm 0.3 \%$ for $\delta^{15} \mathrm{~N}$. As lipids are depleted in ${ }^{13} \mathrm{C}$ (DeNiro and Epstein, 1977), any variation in lipid concentrations among fish replicates could influence comparisons of $\delta^{13} \mathrm{C}$. However, in this study, the variation in mean $\mathrm{C}: \mathrm{N}$ ratios (a correlate of lipid concentration) among fish replicates was very low $(3.2 \pm 0.1)$ and the correlation between $\mathrm{C}: \mathrm{N}$ and $\delta{ }^{13} \mathrm{C}$ values of fish was insignificant (Spearmen rank order correlation: $\rho=-0.096, P>0.1)$. Therefore, fish $\delta^{13} \mathrm{C}$ data were not arithmetically lipid-normalised. Macroinvertebrate $\delta^{13} \mathrm{C}$ values were left uncorrected as well.

\subsection{Trophic level calculations}

Due to great temporal and spatial variability of stable isotope (SI) composition in primary producers in lakes, the trophic position (TP) of investigated consumers was reconstructed using SI signatures of several primary consumers (Post, 2002). Filter-feeding zooplankton is usually considered as an integrator of the pelagic phytoplankton signature and gastropods of benthic or littoral algal sources (Post, 2002). We used enriched pelagic primary consumer (zooplankton: Daphnia spp., Tab. 2) as a baseline (base 1) for the pelagic $\delta^{13} \mathrm{C}$ signature. As a baseline (Base 2) for the littoral $\delta^{13} \mathrm{C}$ signature, we used depleted littoral primary consumer (gastropods: Radix sp., Tab. 2). Overall, we used two isotopically distinct primary consumers to calculate the trophic position of the investigated consumers by the equation (Post, 2002):

$$
\begin{aligned}
\mathrm{TP}= & 2+\left(\delta^{15} \mathrm{~N}_{\text {consumer }}-\left[\delta^{15} \mathrm{~N}_{\text {base } 1} \times \alpha+\delta^{15} \mathrm{~N}_{\text {base } 2}\right.\right. \\
& \times(1-\alpha)]) \times 2.9^{-1}
\end{aligned}
$$

where $\delta^{15} \mathrm{~N}$ consumer is the nitrogen isotope ratio in a consumer of interest; $\delta^{15} \mathrm{~N}_{\text {baseline }}$ is the nitrogen isotopic baseline of a primary consumer, corresponding to $\mathrm{TP}=2 ; \alpha$ is the proportion of nitrogen isotopes in a consumer, ultimately derived from sources similar to gastropods (base 1). Assuming that the rate of nitrogen and carbon flow from the diet to the
Table 2. Summary of the stable isotope analysis of the baseline organisms used for trophic position calculation (Daphnia spp., Radix sp.) from the lakes studied: stable isotope values $\left(\delta^{13} \mathrm{C}, \delta^{15} \mathrm{~N}, \%\right.$ ).

\begin{tabular}{llllll}
\hline \multirow{2}{*}{ Lake } & \multicolumn{2}{c}{ Daphnia spp. } & & \multicolumn{2}{c}{ Radix sp. } \\
\cline { 2 - 3 } \cline { 5 - 6 } & $\delta^{13} \mathrm{C}$ & $\delta^{15} \mathrm{~N}$ & & $\delta^{13} \mathrm{C}$ & $\delta^{15} \mathrm{~N}$ \\
\hline Aisetas & -33.1 & 14.4 & & -31.9 & 11.8 \\
Antaliepte & -32.9 & 7.1 & & -27.2 & 2.9 \\
Asveja & -35.1 & 9.6 & & -29.8 & 7.0 \\
Baluošas & -34.5 & 7.9 & & -29.3 & 5.7 \\
Daugai & -29.6 & 7.1 & & -23.7 & 4.6 \\
Drūkšiai & -28.0 & 2.2 & & -24.0 & 4.4 \\
Dusia & -29.3 & 9.1 & & -23.8 & 3.3 \\
Luodis & -31.3 & 10.3 & & -27.5 & 8.8 \\
Lūšiai & -33.7 & 6.5 & & -30.7 & 5.5 \\
Plateliai & -27.3 & 7.7 & & -23.3 & 4.2 \\
Zarasas & -33.0 & 12.1 & & -27.1 & 10.3 \\
Žeimenys & -34.9 & 7.7 & -30.4 & 6.2 \\
\hline
\end{tabular}

predator is the same, $\alpha$ was estimated using $\delta^{13} \mathrm{C}$ by the equation (Post, 2002):

$$
\alpha=\left(\delta^{13} \mathrm{C}_{\text {consumer }}-\delta^{13} \mathrm{C}_{\text {base } 2}\right) \times\left(\delta^{13} \mathrm{C}_{\text {base } 1}-\delta^{13} \mathrm{C}_{\text {base } 2}\right)-1 .
$$

This two-end-member-mixing model allows differentiation between such two sources as littoral and pelagic food webs, and assumes that there is little trophic fractionation of carbon, and mixing is linear (Post, 2002). It also assumes that the fractionation factors between resources and consumers incorporated into the model were $0.39 \pm 1.3 \%$ for $\delta^{13} \mathrm{C}$ and $3.4 \pm 0.98 \%$ o for $\delta^{15} \mathrm{~N}$ (Post, 2002).

\section{Results}

\subsection{Mysids diet}

The analysis of $P$. lacustris diet showed that adults $(11.2 \pm 0.8 \mathrm{~mm})$ mainly fed on phytoplankton (Fig. 1). On average, phytoplankton accounted for $40.7 \pm 0.02 \%$ of the studied mysids diet. However, the gut content analysis showed that the share of zooplankton (Rotatoria, Cladocera, Copepoda) and benthic macroinvertebrates (Oligochaeta, Chironomidae) in the diet of mysids was also significant. Altogether, "animal" prey (primary consumers) accounted for $37.1 \pm 0.1 \%$ of the mysids diet in the lakes studied (Fig. 1).

\subsection{Variations in perch diet}

Evident differences in the diet content of first-year $(0+)$ $P$. Aluviatilis were recorded in lakes with and without the introduced $P$. lacustris (Fig. 2). The diet of P. fluviatilis juveniles was clearly dominated by zooplankton in the lakes devoid of the introduced mysids. Zooplankton constituted more than $80 \%$ of the studied perch diet in theses lakes. Meanwhile, mysids were the dominant prey in the lakes where the introduced $P$. lacustris were present. The contribution of mysids to the diet of $P$. fluviatilis juveniles in these lakes reached more than $50 \%$ (Fig. 2). 


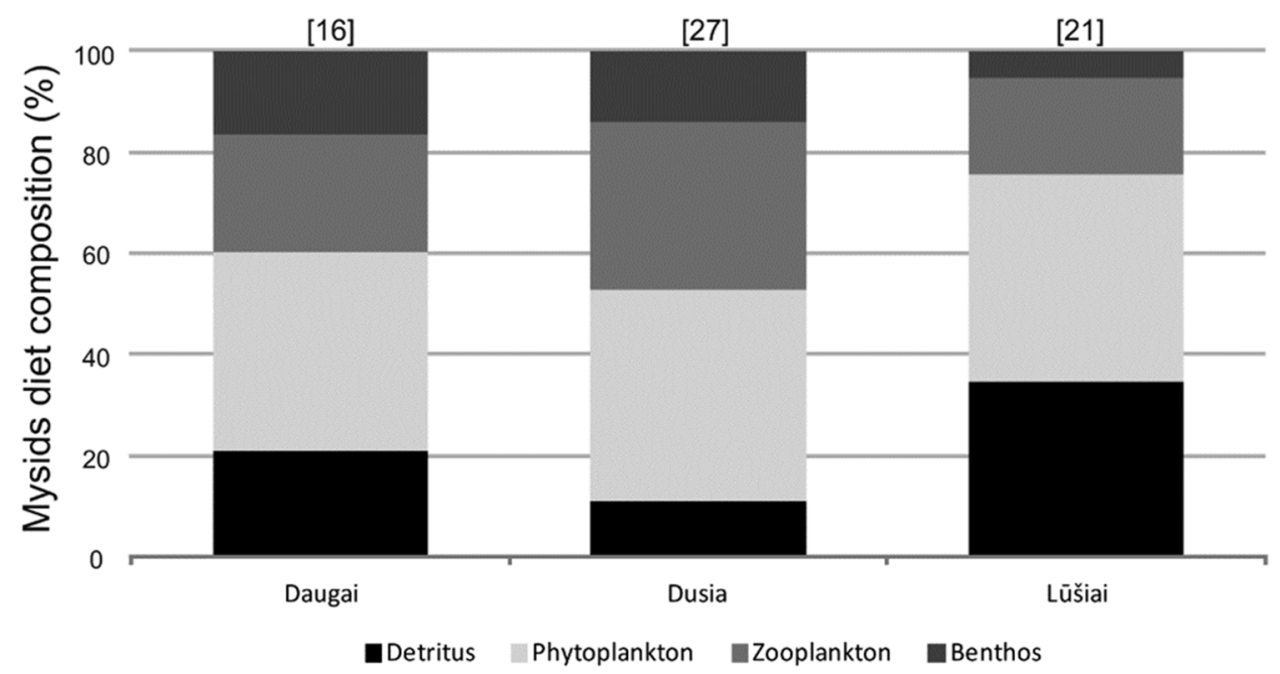

Fig. 1. Mean diet composition (volume percentage) of Paramysis lacustris from the lakes studied. Numbers of the specimens used for gut content estimates are given in square brackets.

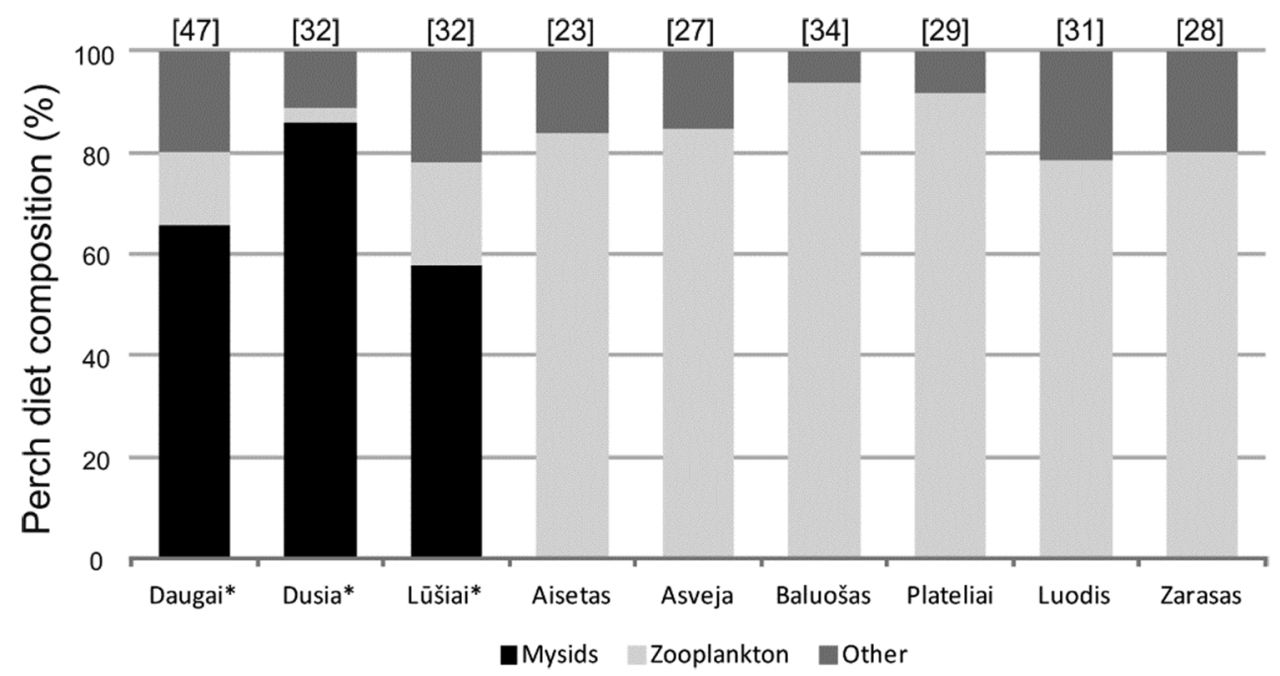

Fig. 2. Mean diet composition (weight percentage) of Perca fluviatilis juvenile from the lakes studied. Numbers of the specimens used for gut content estimates are given in square brackets. The presence of Paramysis lacustris is denoted by an asterisk.

In the lakes devoid of mysids, the mean share of consumed zooplankton in $P$. fluviatilis stomachs was $85.2 \pm 6.1 \%$. Meanwhile, the share of consumed zooplankton in stomachs of $P$. fluviatilis from the lakes inhabited by the introduced $P$. lacustris was only $12.4 \pm 8.9 \%$. Such a difference in zooplankton consumption between the lakes inhabited by the introduced mysids and the lakes devoid of them was statistically significant (Mann-Whitney $U$ test: $Z=2.32$, $P=0.020)$.

\subsection{Stable isotope analysis (SIA)}

The performed stable isotope analysis showed that in the lakes studied, zooplankton is a primary consumer. The mean trophic position (TP) of zooplankton was found to be
$2.0 \pm 0.02$. It did not vary between the lakes (Kruskal-Wallis ANOVA test: $H(5, N=18)=2.60, P=0.76)$.

The summary of $P$. lacustris SIA results is presented in Table 3. According to SIA results, the mean TP of P. lacustris was $3.2 \pm 0.2$, which suggests that in the littoral zone of the lakes studied mysids are second-level consumers. The performed analysis also showed that $P$. lacustris occupied a higher trophic position in the lake food chain than zooplankton (Fig. 3). Their TP was significantly higher than that of zooplankton (Mann-Whitney $U$ test: $Z=2.88, P=0.004$ ).

The summary of $P$. fluviatilis SIA results is presented in Table 4. The mean TP of perch juveniles $(0+$ age $)$ was $4.1 \pm 0.3$ in the lakes containing $P$. lacustris populations, and it was significantly higher than that in the lakes devoid of invasive mysids populations $-3.4 \pm 0.2$ (Mann-Whitney $U$ test, 
Table 3. Summary of the stable isotope analysis of Paramysis lacustris from the lakes studied: number of replicates $(N)$, stable isotope values $\left(\delta^{13} \mathrm{C}, \delta^{15} \mathrm{~N}, \%\right)$, and trophic position (TP).

\begin{tabular}{|c|c|c|c|c|}
\hline \multirow[t]{2}{*}{ Lake } & \multirow[t]{2}{*}{$N$} & $\delta^{13} \mathrm{C}$ & \multirow{2}{*}{$\frac{\delta^{15} \mathrm{~N}}{\text { Mean } \pm \mathrm{SD}}$} & \multirow{2}{*}{$\frac{\mathrm{TP}}{\mathrm{Mean} \pm \mathrm{SD}}$} \\
\hline & & Mean \pm SD & & \\
\hline Antalieptè & 3 & $-28.2 \pm 0.1$ & $8.2 \pm 0.1$ & $3.4 \pm 0.1$ \\
\hline Daugai & 7 & $-28.3 \pm 2.1$ & $9.9 \pm 1.8$ & $3.0 \pm 0.3$ \\
\hline Drūkšiai & 7 & $-26.2 \pm 3.2$ & $7.4 \pm 3.3$ & $3.2 \pm 1.4$ \\
\hline Dusia & 6 & $-22.8 \pm 3.1$ & $7.6 \pm 1.8$ & $3.6 \pm 0.4$ \\
\hline Lūšiai & 8 & $-32.1 \pm 1.2$ & $9.5 \pm 1.7$ & $3.0 \pm 0.4$ \\
\hline Žeimenys & 3 & $-32.2 \pm 0.5$ & $10.7 \pm 0.3$ & $3.1 \pm 0.1$ \\
\hline
\end{tabular}

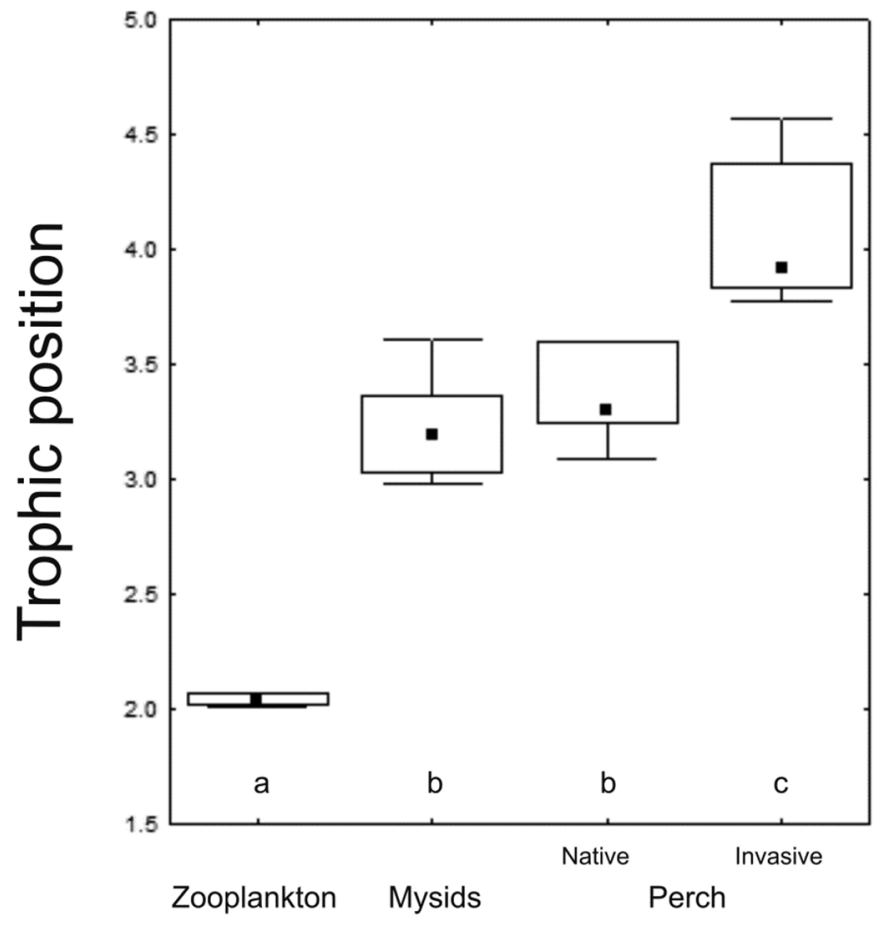

Fig. 3. The trophic position of zooplankton (Daphnia ssp.), Mysids (Paramysis lacustris) and juvenile perch (Perca fluviatilis) in the lakes studied. Differences in the trophic position of perch in the presence (Invasive) and absence (Native) of P. lacustris in lakes. Significant differences between the groups (Mann-Whitney U test: $P<0.05)$ are indicated by lowercase letters $(\mathrm{a}, \mathrm{b}, \mathrm{c})$.

$Z=2.88, P=0.004$, Fig. 3). Furthermore, TP of perch juveniles from the lakes without invasive mysids was similar to that of $P$. lacustris from the lakes harbouring this invasive species (Mann-Whitney $U$ test, $Z=0.96, P=0.33$, Fig. 3).

\section{Discussion}

In accordance with recent knowledge, $P$. lacustris is defined as an omnivore-herbivore species that feeds by gathering and filtering, although in some periods, zooplankton and other benthic invertebrates may constitute a significant
Table 4. Summary of the stable isotope analysis of Perca fluviatilis from the lakes studied: number of replicates $(N)$, stable isotope values $\left(\delta^{13} \mathrm{C}, \delta^{15} \mathrm{~N}, \%\right)$, and trophic position (TP). The presence of Paramysis lacustris in the lakes is denoted by an asterisk.

\begin{tabular}{|c|c|c|c|c|}
\hline \multirow[t]{2}{*}{ Lake } & \multirow[t]{2}{*}{$N$} & $\delta^{13} C$ & $\delta^{15} N$ & $T P$ \\
\hline & & Mean \pm SD & Mean \pm SD & Mean \pm SD \\
\hline Aisetas & 4 & $-31.6 \pm 1.0$ & $15.7 \pm 0.9$ & $3.3 \pm 0.6$ \\
\hline Antaliepte* & 3 & $-31.2 \pm 0.1$ & $12.3 \pm 0.3$ & $3.8 \pm 0.1$ \\
\hline Asveja & 3 & $-32.3 \pm 0.2$ & $12.6 \pm 0.2$ & $3.3 \pm 0.1$ \\
\hline Baluošas & 3 & $-31.0 \pm 0.5$ & $10.7 \pm 0.5$ & $3.2 \pm 0.1$ \\
\hline Daugai* & 6 & $-27.4 \pm 0.6$ & $12.2 \pm 0.6$ & $3.8 \pm 0.1$ \\
\hline Drūkšiai* & 6 & $-26.7 \pm 1.5$ & $11.0 \pm 0.8$ & $4.4 \pm 0.5$ \\
\hline Dusia* & 3 & $-25.3 \pm 0.7$ & $13.6 \pm 0.2$ & $4.6 \pm 0.3$ \\
\hline Luodis & 3 & $-28.2 \pm 0.1$ & $14.5 \pm 0.1$ & $3.6 \pm 0.1$ \\
\hline Lūšiai* & 5 & $-30.7 \pm 0.5$ & $12.2 \pm 0.7$ & $4.0 \pm 0.2$ \\
\hline Plateliai & 3 & $-23.0 \pm 0.7$ & $9.3 \pm 0.5$ & $3.6 \pm 0.1$ \\
\hline Zarasas & 4 & $-31.7 \pm 0.1$ & $15.4 \pm 0.1$ & $3.1 \pm 0.1$ \\
\hline Žeimenys* & 6 & $-31.9 \pm 0.6$ & $13.1 \pm 0.9$ & $3.9 \pm 0.3$ \\
\hline
\end{tabular}

part of these mysids' diet (Komarova, 1991; Jankauskiene, 2003; Lesutienè et al., 2007). Such high dietary diversity of mysids implies a variety of possible functional roles in ecosystem food webs and difficulties in predicting their trophic linkages and extrapolating from one ecosystem to another. It is still not clear which trophic level P. lacustris occupy in temperate lakes. If zooplankton constitutes a significant part of their diet, $P$. lacustris may be a secondary consumer in the lake littoral. This fact suggests that adults of $P$. lacustris occupy a higher position in the trophic chain than zooplankton. Apparent predation of mysids on zooplankton may lengthen the food chain in lakes. If these mysids reduce zooplankton population density or induce changes in zooplankton species richness and diversity, zooplanktivorous fish may shift their diet from zooplankton to mysids, consequently, the food chain length will be increased. This study revealed that the introduction of $P$. lacustris may lead to the additional trophic level incorporation into the food chain of zooplanktivorous fish in temperate lakes.

\subsection{Trophic position of $P$. lacustris}

The performed gut content analysis revealed that phytoplankton is the dominant prey for P. lacustris. However, prey of animal origin also contributed significantly to their diet in the lakes studied. Thus, according to the gut content analysis, the tropic position of $P$. lacustris is somewhere inbetween the second and the third trophic levels. Meanwhile, SIA revealed $P$. lacustris as slightly more predaceous consumer (third trophic level) in studied lakes. Such a discrepancy may be explained by different methods employed for mysids diet analysis and the timing of mysids collection for their diet analysis.

Information on the diet of mysids is often obtained through gut content analysis (Mauchline, 1980; Johannsson et al., 2001; Jankauskiené, 2003) or captive feeding trials (Komarova, 1991; Fink et al., 2012). However, the diet of 
mysids cannot be accurately identified employing these direct methods because some of the prey get over-digested (mysids tend to macerate their prey beyond recognition) and such analyses reveal only undigested food remains or very recently ingested prey. Further disadvantages of gut content analysis include the following. Firstly, gut content analysis shows only what has been actually ingested rather than what has been assimilated and, secondly, it provides only a recent "snapshot" of the diet depending on the rate of digestion (Gearing, 1991). Meanwhile, stable isotopes signature integrates assimilated dietary source, providing time-integrated indication of the animal diet (Tieszen et al., 1983; Grey, 2006). Body tissues of mysids contain the information on their diet accumulated over a period of several months (Gorokhova and Hansson, 1999; Johannsson et al., 2001). Furthermore, some of the ingested prey might have higher nutritional value than others. For instance, Siegfried and Kopache (1980) revealed that Neomysis mercedis Holmes, 1896 gets $80 \%$ of all the energy from feeding on mesozooplankton. This fact suggests that animal prey might have higher nutritional value and, consequently a stronger influence on the isotope composition of $P$. lacustris. If correct, this assumption explains why the trophic level values obtained from SIA are a bit higher than those obtained from gut content analyses.

On the other hand, mysids are known for their diel vertical migration from the lake bottom to the water column ( $\mathrm{Gal}$ et al., 1999; Johannsson et al., 2001; Lasenby and Shi, 2004). Previous studies showed that during the daytime, $P$. lacustris feed on detritus and phytoplankton near the sediment, and at night, migrate vertically to feed on mesozooplankton (Jankauskienè, 2003). In this study, for diet analysis, mysids were collected during the daytime, thus their gut content reflects rather a sedimentary diet that is dominated by detritus and phytoplankton. Meanwhile, SIA results represent the time-integrated diet content including a more predaceous nocturnal diet on mesozooplankton. Consequently, detritus and phytoplankton might be overrepresented in the mysids stomach content in comparison to the more predatory nocturnal feeding as indicated by stable isotope signatures. This fact could also explain the slightly higher trophic level values obtained from SIA than those obtained from gut content analyses.

Overall, this study revealed that in the lakes studied, $P$. lacustris is an omnivorous consumer with a propensity for carnivory. Therefore, it may affect local food webs both as a consumer (top-down effects) and novel prey for native predators (bottom-up effects). As an omnivorous consumer, $P$. lacustris can simultaneously act as a competitor of local zooplankton for resources (phytoplankton) and as a predator on small zooplankton. Our finding that $P$. lacustris consumes a significant share of secondary production in lakes is consistent with results of the similar studies conducted in lagoon ecosystems. The gut content analysis of $P$. lacustris showed that zooplankton crustaceans constitute a significant share of mysids diet in the Curonian Lagoon, especially at night when mysids migrate vertically (Jankauskiene, 2003). Previously performed stable isotope analysis also showed that zooplankton forms a very significant part of P. lacustris diet in the Curonian Lagoon (Lesutiené et al., 2007). Furthermore, it showed that zooplankton dominate P. lacustris diet in summer when zooplankton are easily available and abundant (Lesutienè et al., 2007). Overall, results of this study are in agreement with those of other studies performed in various habitats with $P$. lacustris featuring as a second order consumer (Lesutiene et al., 2007; Arbačiauskas et al., 2013). Furthermore, carnivory has also been indicated for other invasive mysids of Ponto-Caspian origin, i.e. Hemimysis anomala, G. O. Sars., 1907, Limnomysis benedeni Czerniavsky, 1882 (Ketelaars et al., 1999; Borcherding et al., 2006; Fink et al., 2012; Ricciardi et al., 2012).

\subsection{Changes in perch diet}

The performed perch diet analysis revealed evident changes in proportions of the main prey organisms in the diet of juvenile perch at their zooplanktivorous feeding stage. A significant difference was observed in consumption of zooplankton and invasive mysids. This study revealed that in the presence of $P$. lacustris, perch juveniles mostly feed on mysids and in their absence, almost exclusively on zooplankton. In general, in the course of perch ontogeny, its feeding niche undergoes changes. When a juvenile, perch is a zooplankton feeder, later it shifts to feeding on macroinvertebrates of an intermediate size and, when large enough, to a diet mainly consisting of fish (Hjelm et al., 2000). Meanwhile, other studies showed juvenile perch to be an opportunistic feeder. It was revealed that perch juveniles consume prey that is available, easy to cope with and suitable as food by their size (Svanbäck and Eklöv 2002; Rakauskas et al., 2010). Furthermore, previous studies revealed that in the presence of introduced PontoCaspian mysids, at least when they are abundant, the shift in the diet of perch juveniles from feeding on zooplankton to macroinvertebrates occurs at an earlier age (Rakauskas et al., 2010). Furthermore, perch juveniles were also found to show a strong feeding preference for invasive PontoCaspian mysids in Europe (Borcherding et al., 2006; Rakauskas et al., 2010). This fact suggests that littoral mysids are very important for perch juveniles at the transitional stage when their feeding shifts from zooplankton to benthos. Similar feeding trends were also revealed for pikeperch, Sander lucioperca (Linnaeus, 1758) another percid species of European lakes. It was revealed that pikeperch juveniles feed predominantly on Ponto-Caspian mysids during their ontogenetic feeding transition from feeding on zooplankton to fish fry (Ložys, 2003).

Overall, in the presence of invasive P. lacustris, secondary consumer prey (mysids) replaces the primary consumer prey (zooplankton) in juvenile perch diet. Consequently, $P$. fluviatilis juveniles become tertiary consumers (fourth trophic level) in lakes inhabited by P. lacustris (Fig. 4). Unfortunately, we failed to find any studies on the perch trophic level in temperate lakes with littoral mysids, although, other studies also showed perch juveniles to be secondary consumers in temperate lakes without littoral mysids. Surprisingly, Syväranta et al. (2011) indicated the same trophic position $(\mathrm{TP}=3.4)$ of juvenile perch by SIA as the one determined in this study in lakes without invasive mysids. Therefore, our study clearly shows changes in the trophic level of perch juveniles associated with $P$. lacustris invasion and supports the 


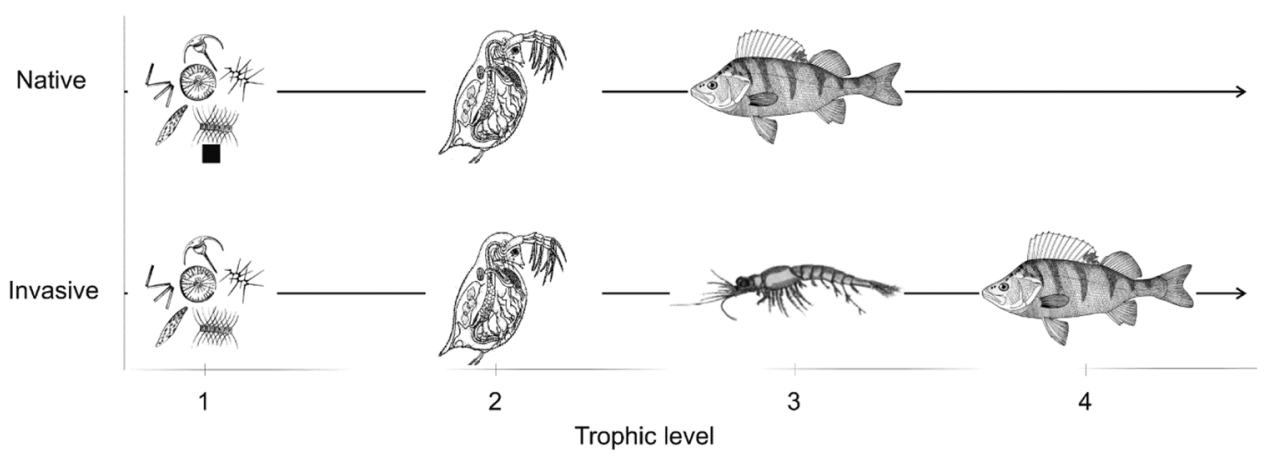

Fig. 4. Lengthening of the hypothetical food chain after Paramysis lacustris introduction into temperate mesotrophic lakes.

theory that invasion of non-indigenous mysids can arouse changes in the diet of native predators and alter local food webs (Lasenby et al., 1986; Spencer et al., 1991; Rakauskas et al., 2010; Ricciardi et al., 2012).

\section{Conclusions}

Before its introduction into water bodies, $P$. lacustris was thought to be a primary consumer. It was believed these mysids are herbivorous or detritivorous in the littoral zone of lakes (Gasiūnas, 1965, 1972; Vaitonis et al., 1990). Thus, it was expected that their introduction would increase the consumption of detritus and plants and enhance incorporation of herbivorous production in food webs of mesotrophic lakes. However, this study revealed that $P$. lacustris are also potential predators of zooplankton and benthic invertebrates. As they consume a significant amount of animal-origin prey, $P$. lacustris constitute the third trophic level in the littoral zone of lakes. That is, probably, another important aspect of $P$. lacustris invasion into mesotrophic lakes. Being predacious enough to be a secondary consumer in lakes, $P$. lacustris may increase the food chain length at least for zooplanktivorous fish juveniles (Fig. 4). Such results are in line with the findings reported from other cases of mysid species introduction, which showed that mysid introduction could have profound impacts on fisheries. It was revealed that the introduced M. relicta are associated with declines in growth, abundance and productivity of planktivorous fishes in the lakes of North America (Lasenby et al., 1986; Bowles et al., 1991; Spencer et al., 1991; Tohtz, 1993) or Scandinavia (Lasenby et al., 1986; Langeland et al., 1991). Furthermore, similar food chain lengthening for planktivorous fish species has been distinguished for another invasive mysid species of the Ponto-Caspian origin i.e., $H$. anomala (Ricciardi et al., 2012). Overall, the assumption that $P$. lacustris invasion may have no whole-ecosystem consequences, as it was though before their introduction, is not correct. The invasion of Ponto-Caspian mysids such as $P$. lacustris can affect the food web structure of invaded habitats at multiple levels and thus potentially have complex wholeecosystem consequences.

Acknowledgements. This work, stable isotope analysis in particular, was supported by the Research Council of Lithuania, Project No. LEK-18/2010.

\section{References}

Anonymous. 2015. Ežeru ir tvenkiniu būklè. 2015 valstybiniu ežeru monitoringo duomenys [The conditions of lakes and ponds. 2015 monitoring data of state lakes]. Aplinkos apsaugos agentūra, Vilnius. (In Lithuanian). Available from http://vanduo.gamta.lt/ cms/. Accessed on 03 June 2015.

Arbačiauskas K, Rakauskas V, Virbickas T. 2010. Initial and longterm consequences of attempts to improve fish-food resources in Lithuanian waters by introducing alien peracaridan species: a retrospective overview. J Appl Ichthyol 26: 28-37.

Arbačiauskas K, Višinskienė G, Smilgevičienė S, Rakauskas V. 2012. Nonindigenous macroinvertebrate species in Lithuanian fresh waters, Part 1: Distributions, dispersal and future. Knowl Manag Aquat Ecosyst 402: 1-18.

Arbačiauskas K, Lesutienė J, Gasiūnaite ZR. 2013. Feeding strategies and elemental composition in Ponto-Caspian peracaridans from contrasting environments: can stoichiometric plasticity promote invasion success? Freshwater Biol 58: 1052-1068.

Arbačiauskas K, Šidagyte E, Šniaukštaite V, Lesutienė J. 2018. Range expansion of Ponto-Caspian peracaridan Crustaceans in the Baltic Sea basin and its aftermath: Lessons from Lithuania. Aquat Ecosyst Health 20: 393-401.

Audzijonytė A, Baltrūnaitė L, Väinölä R, Arbačiauskas K. 2017. Human-mediated lineage admixture in an expanding Ponto Caspian crustacean species Paramysis lacustris created a novel genetic stock that now occupies European waters. Biol Invasions 19: 2443-2457.

Borcherding J, Murawski S, Arndt H. 2006. Populations ecology, vertical migration and feeding of the Ponto-Caspian invader Hemimysis anomala in a gravel-pit lake connected to the River Rhine. Freshwater Biol 51: 2376-2387.

Borodich ND, Havlena FK. 1973. The biology of mysids acclimatized in the reservoirs of the Volga River. Hidrobiologia 42: 527-539.

Borza P, Kovács K, György A, Török JK, Egri A. 2019. The PontoCaspian mysid Paramysis lacustris (Czerniavsky, 1882) has colonized the Middle Danube. Knowl Manag Aquat Ecosyst 420: 1 .

Bowles EC, Rieman BE, Mauser GR, Bennett D.H. 1991. Effects of introductions of Mysis relicta on fisheries in Northern Idaho. American Fisheries Society Symposium 9: 65-74.

Bubinas A. 1979. Feeding of fish in the Kaunas hydro-electric plant water reservoir by acclimatized in it Mysidae of Mesomysis kowalewskyi Czern. (Paramysis lacustris) of the Caspian complex [Pitanije ryb vodokhranilischa Kaunasskoj GES akklimatizirovannymi $\mathrm{v}$ nem mizidami Kaspijskogo reliktovogo kompleksa 
Mesomysis kowalewskyi Czern. (Paramysis lacustris)]. LTSR MA Darbai, Serija B 88: 79-85 (In Russian).

Chess DW, Stanford JW. 1998. Comparative energetics and life cycle of the opossum shrimp (Mysis relicta) in native and non-native environments. Freshw Biol, in press.

David P, Thébault E, Anneville O, Duyck PF, Chapuis E, Loeuille N. 2017. Chapter One - Impacts of Invasive Species on Food Webs: A Review of Empirical Data. Adv Ecol Res 56: 1-60.

DeNiro M, Epstein S. 1977. Mechanism of carbon isotope fractionation associated with lipid synthesis. Science 197: 261-263.

Feuchtmayr H, Grey J. 2003. Effect of preparation and preservation procedures on carbon and nitrogen stable isotope determinations from zooplankton. Rapid Commun Mass Spectrom 17: 2605-2610.

Fink P, Kottsieper A, Heynen M, Borcherding J. 2012. Selective zooplanktivory of an invasive Ponto-Caspian mysid and possible consequences for the zooplankton community structure of invaded habitats. Aquat Sci 74: 191-202.

Gal G, Loew ER, Rudstam LG, Mohammadian M.A. 1999. Light and diel vertical migration: spectral sensitivity and light avoidance by Mysis relicta. Can J Fish Aquat Sci 56: 311-322.

Gasiūnas I. 1963. The acclimatization of fodder crustaceans (of the Caspian relict type) into the reservoir of Kaunas Hydroelectric power station and the possibility of their transference into other water bodies in Lithuania [Akklimatizacija kormovykh rakoobraznykh (Kaspijskogo reliktovogo tipa) v vodokhranilische Kaunasskoj GES i vozmozhnosti ikh pereselenija v drugie vodojemy Litvy]. LTSR MA Darbai Serija C 1: 79-85 (In Russian).

Gasiunas I. 1965. On the results of the acclimatization of food invertebrates of the Caspian complex in Lithuanian water bodies [O rezultatakh akklimatizacii kormovykh bespozvonochnykh Kaspijskogo kompleksa v vodoemakh Litvy]. Zoologicheskij Zhurnal 44; 340-343 (In Russian).

Gasiūnas I. 1972. Enrichment of fodder basis of water bodies of Lithuania by acclimatized crustaceans-like organisms from the Caspian Sea complex [Obogoschenie kormovoj bazy ryb vodoemov Litvy akklimatizirovannymi rakoobraznymi Kaspijskogo kompleksa]. In: Maniukas J, Virbickas J. (Eds). On the breeding of fish and crustacean-like organisms in the water bodies of Lithuania [Voprosy razvedenija ryb i rakoobraznykh $\mathrm{v}$ vodoemakh Litvy]. Vilnius, Lithuania: Mintis Publishers, pp. 57-68 (In Russian).

Gearing JN. 1991. The study of diet and trophic relationships through natural abundance ${ }^{13} \mathrm{C}$. In: Coleman DC, Fry B. (Eds). Carbon Isotope techniques. San Diego: Academic Press, pp. 201-218.

Gorokhova E, Hansson S. 1999. An experimental study on variations in stable carbon and nitrogen isotopes fractionation during growth of Mysis mixta and Neomysis integer. Can J Fish Aquat Sci 56: $2203-2210$

Grey J. 2006. The use of stable isotope analyses in freshwater ecology: current awareness. Pol J Ecol 54: 563-584.

Hjelm J, Persson L, Christensen B. 2000. Growth, morphological variation and ontogenetic niche shifts in perch (Perca flviatilis) in relation to resource availability. Oecologia 122: 190-199.

Hyslop EJ. 1980. Stomach contents analysis - a review of methods and their application. J Fish Biol 17: 411-429.

Jackson MC, Wasserman RJ, Grey J, Ricciardi A, Dick JTA, Alexander ME. 2017. Chapter Two - Novel and Disrupted Trophic Links Following Invasion in Freshwater Ecosystems. Adv Ecol Res 57: 55-97.
Jankauskienė R. 2003. Selective feeding of Ponto-Caspian higher crustaceans and fish larvae in the littoral zone of the Curonian Lagoon. Ekologija 2: 19-27.

Johannsson OE, Leggett MF, Rudstam LG, Servos MR, Mohammadian MA, Gal G, Dermott RM, Hesslein RH. 2001. Diet of Mysis relicta in Lake Ontario as revealed by stable isotope and gut content analysis. Can J Fish Aquat Sci 58: 1975-1986.

Ketelaars HAM, Lambregts-van de Clundert FE, Carpentier CJ, Wagenvoort AJ, Hoogenboezem W. 1999. Ecological effects of the mass occurrence of the Ponto Caspian invader, Hemimysis anomala G. O. Sars., 1907 (Crustacea: Mysidacea), in a freshwater storage reservoir and in the Netherlands, with notes on its autecology and new records. Hydrobiologia 394: 233-248.

Koksvik J, Reinertsen H, Langeland A. 1991. Changes in planktono biomass and species composition in Lakes Jonsvatn, Norway, following the establishment of Mysis relicta. Am Fish S S 9: 115-125.

Komarova TI. 1991. Mysids (Mysidacea). Fauna Ukrainy 26 (7). Kiev: Akademia Nauk Ukrainy, 104 (In Russian).

Kublickas A, Bubinas A. 1985. The effect of acclimatized crustacea on the fsh nutrition in the littoral zone of the Curonian Lagoon [Роль акклиматизированных ракообразных в питании рыб литоральной зоны Куршского залива]. Acta Hydrobiologica Lituanica 5: 80-85 (In Russian).

Langeland A, Koksvik JI, Nydal. 1991. Impact of the introduction of Mysis relicta on the zooplankton and fish populations in a Norwegian lake. Am Fish S S 9: 98-114.

Lasenby DC, Northcote TG, Furst M. 1986. Theory, practise, and effects of Mysids relicta introductions to North American and Scandinavian lakes. Can J Fish Aquat Sci 43: 1277-1284.

Lasenby DC, Shi Y. 2004. Changes in the elemental composition of the stomach contents of the opossum shrimp Mysis relicta during diel vertical migration. Can J Zool 82: 525-528.

Lesutienè J, Gorokhova E, Gasiunaite ZR, Razinkovas A. 2007. Isotopic evidence for zooplankton as an important food source for the mysid Paramysis lacustrisin the Curonian Lagoon, the SouthEastern Baltic Sea. Estuar Coast Shelf S 73: 73-80.

Ložys L. 2003. Seasonal migrations of pikeperch (Sander lucioperca L.) from the Curonian lagoon to the Baltic Sea and advantages of the phenomenon. Acta Zool Litu 13: 188-194.

Mauchline, J. 1980. The biology of mysids and euphausids. Adv Mar Biol 18: 81-97.

Post DM. 2002. Using stable isotopes to estimate trophic position: models, methods, and assumptions. Ecology 83: 703-718.

Rakauskas V, Smilgevičienė S, Arbačiauskas K. 2010. The impact of introduced Ponto-Caspian amphipods and mysids on perch (Perca fluviatilis) diet in Lithuanian lakes. Acta Zoolog Lituanica 20: 189-197.

Ricciardi A, Avlijas S, Marty J. 2012. Forecasting the ecological impacts of the Hemimysis anomala invasion in North America: Lessons from other freshwater mysids introductions. J Great Lakes Res 38: 7-13.

Rieman BE, Falter CM. 1981. Effects of the establishment of Mysis relicta on the macrozooplankton of a large lake. Trans Am Fish Soc 110: 613-620.

Siegfried CA, Kopache ME. 1980. Feeding of Neomysis merceddis (Holmes). Biol Bull 159: 193-205.

Spencer CN, McClelland BR, Stanford JA. 1991. Shrimp stocking, salmon collapse and eagle displacement: cascading interactions in the food web of a large aquatic ecosystem. BioScience 41, 14-21.

Spencer CN, Potter DS, Bukantis RT, Stanford JA. 1999. Impact of predation by Mysis relicta on zooplankton in Flathead Lake, Montana, USA. J Plankton Res 21: 51-64. 
Svanbäck R, Eklöv P. 2002. Effects of habitat and food resources on morphology and ontogenetic growth trajectories in perch. Oecologia 131: 61-70.

Syväranta J, Högmander P, Keskinen T, Karjalainen J, Jones RI. 2011. Altered energy flow pathways in a lake ecosystem following manipulation of fish community structure. Aquat Sci 73: 79-89.

Tieszen LL, Boutton TW, Tesdahl K, Slade NA. 1983. Fractionation and turnover of stable carbon isotopes in animal tissues: implications for $\delta^{13} \mathrm{C}$ analysis of diet. Oecologia 57: 32-37.

Tohtz J. 1993. Lake whitefish diet and growth after the introduction of Mysis relicta to Flathead Lake, Montana. Trans Am Fish Soc 122: 629-635.
Vaitonis G, Lazauskiene L, Razinkov A. 1990. Study of results of economic efficiency, and perspectives of acclimatization of invertebrates in the Baltic water bodies [Izuchenije rezultatov ekonomicheskoj effektivnosti i perspektivy akklimatizacii bezpozvonochnykh $\mathrm{v}$ vodoemakh Pribaltiki]. Scientific research report, Institute of Ecology, Vilnius, 1-67. (In Russian).

Virbickas T. 2013. Fish fauna studies in Lithuanian rivers and lakes and their ecological status assessment based on the fish fauna metrics [Ichtiofaunos tyrimai bei ekologinès būklès pagal žuvu rodiklius ivertinimas Lietuvos upèse ir ežeruose]. Scientific research report, Environment Protection Agency, Vilnius, Lithuania. (In Lithuanian).

Cite this article as: Rakauskas V. 2019. The impact of introduced Ponto-Caspian mysids (Paramysis lacustris) on the trophic position of perch (Perca fluviatilis) in European mesotrophic lakes. Knowl. Manag. Aquat. Ecosyst., 420, 38. 